\title{
Zinc and COVID-19
}

\author{
Divya $\mathbf{R}^{*}$ \\ Associate professor, Department of Physiology, Dhanalakshmi Srinivasan Medical college and Hospital, Perambalur, Tamilnadu, \\ India
}

*Corresponding author: Divya R, Associate professor, Department of Physiology, Dhanalakshmi Srinivasan Medical college and Hospital, Perambalur, Tamilnadu, India

ARTICLE INFO

Received: 陆 November 13, 2021

Published: 蔧 November 23, 2021

\section{ABSTRACT}

Citation: Divya R. Zinc and COVID-19. Biomed J Sci \& Tech Res 40(2)-2021. BJSTR. MS.ID.006411.

\section{Editorial}

After iron, Zinc is the second most abundant trace metal in the human body. Zinc has a main role in various cellular functions such as maintenance of immune health. This property of zinc is of great significance in the COVID-19 pandemic. Studies show that Zinc exhibits antiviral activity through inhibition of SARS-CoV RNA polymerase. It also regulates inflammatory response and modulates antiviral and antibacterial immunity. [1,2]

Studies show that Zinc produces significant effect on viral infections by variation in viral fusion, replication and translation of viral protein. Trial show that Zinc supplementation in COVID 19 patients decreased airway neutrophil infiltration and TNF- $\alpha$ release by impeding NF-kB-dependent transcription of inflammatory genes. [1,2] According to recent research Zinc can be used as adjunct therapy for viral life-threatening infections such as
COVID 19. Zinc repletion produces anti-viral effects, moderates the cytokine storm, helps in early recovery, as it causes renewed nucleic acid and protein synthesis. [3] Zinc is an essential nutrient that has antiviral properties. Further research is essential to understand its therapeutic potential against life-threatening viral infections.

\section{References}

1. Pal A, Squitti R, Picozza M, Anil Pawar, Mauro Rongioletti, et al. (2020) Zinc and COVID-19: Basis of Current Clinical Trials. Biol Trace Elem Res, p. 1-11.

2. Skalny AV, Rink L, Ajsuvakova OP, Michael Aschner, Viktor A Gritsenko, et al. (2020) Zinc and respiratory tract infections: Perspectives for COVID-19 (Review). Int J Mol Med 46(1): 17-26.

3. Butters D, Whitehouse M (2021) COVID-19 and nutriceutical therapies, especially using zinc to supplement antimicrobials. Inflammopharmacology 29(1):101-105.
ISSN: 2574-1241

DOI: 10.26717/BJSTR.2021.40.006411

Divya R. Biomed J Sci \& Tech Res

(c) (P) This work is licensed under Creative

Submission Link: https://biomedres.us/submit-manuscript.php

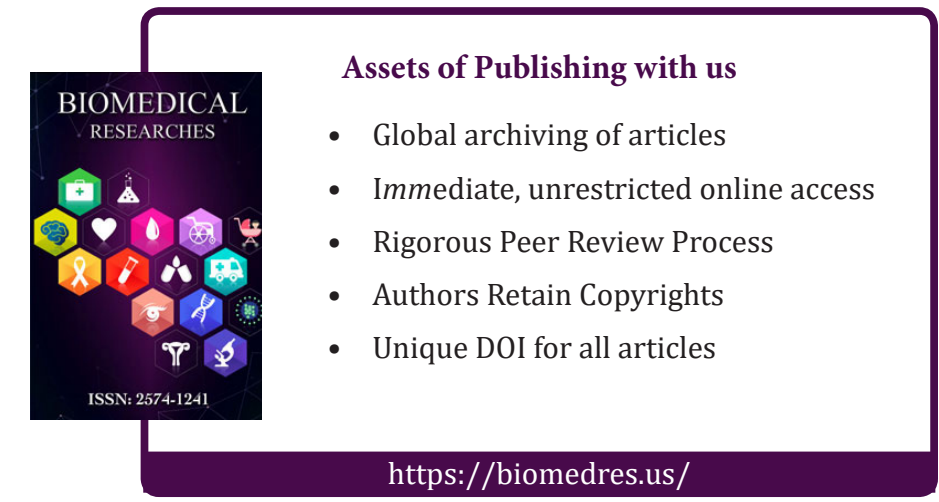

